\title{
A Study on Sexual Assault Victims Attending a Tertiary Care Hospital of Eastern India
}

\author{
Soumyajyoti Bandyopadhay ${ }^{1}$, Somanjana Ghosh ${ }^{2}$, Shouvanik Adhya ${ }^{1}$, \\ Kuhu Pal ${ }^{3}$, Chanchal Kumar Dalai ${ }^{4}$ \\ ${ }^{1}$ (Department of Forensic Medicine, College of Medicine \& JNM Hospital, Kalyani, West Bengal, India) \\ ${ }_{2}^{2}$ (Department of Microbiology, Midnapur Medical College, Midnapur, West Bengal, India) \\ ${ }^{3}$ (Department of Microbiology, College of Medicine \& JNM Hospital, Kalyani, West Bengal, India) \\ ${ }^{4}$ (Department of Pharmacology, College of Medicine \& JNM Hospital, Kalyani, West Bengal, India)
}

\begin{abstract}
Sexual assault on women is an evil trend in the society. Human beings of all age and sex may have the misfortune of experiencing this crime in their lifetime. The present study was conducted on 53 victims of alleged sexual assault with the objectives to reveal their socio demographic profile \& medico legal consequences. The current study shows in most cases the perpetrators of the crime are known to the victim. The victims may or may not have detectable physical injuries. In some cases even in consensual relationship complain of sexual assault comes into play when breach of trust results. Another heinous sort of crime is committed on children who are too young to resist or even understand the consequences of the act. This type of study may help to enhance public awareness, which can increase reporting of incidents and to frame appropriate measures to diminish such events in society.
\end{abstract}

Keywords - Genital injury, Sexual assault, Victim

\section{INTRODUCTION}

Sex related offence has remained a menace to the society since long times. Whatever be the circumstances, sexual crimes create a lifelong scar in the mental set up of the victims, as well as to the relatives of victim. The popular belief in the society that only women are subjected to sexual cruelty and harassment is no longer truth as incidence with young male victims are also common. Whenever an allegation of sex related crime is made the first question which comes to mind of the investigators is whether it is at all true or a false charge. Moreover sex related crimes are one of the most underreported crimes. According to a study of RAINN ${ }^{[1]} 54 \%$ of sexual assaults are not reported to the police, $97 \%$ of rapists will never spend a day in jail and multiple instances of commission of the assault on single women are also common. Despite the advancement of medical technology and even when meticulous clinical examination is done, the importance of circumstantial evidence can never be undermined. Moreover studying the incidences carefully gives important clues with the help of which we can get to the root causes of this social evil and help the society and law enforcing authorities to frame appropriate measures and action to minimize these events.

\section{MATERIALS AND METHODS}

The present cross sectional study was conducted on 53 victims of alleged sexual assault who were brought by police for medical examination at the Department of Forensic Medicine \& Toxicology of a tertiary care Hospital of semi urban area in West Bengal in one year period. Objectives were to know the age distribution of victims, to know the association of physical injuries with the sexual acts, to know the circumstances of the act. Moreover referred patients from hospital who were allegedly sexually violated were also taken into consideration. After proper consent being taken, the actual examination procedure comprising of history taking, general physical examination, and local genital examination was conducted. The victims, if adult ( above 18years) the entire procedure of examination was explained to them and proper consent stating that result of examination may go for or against was obtained. In case of minor, the guardian accompanying the victim was explained and proper consent was taken accordingly. The examination proper was carried out in front of female attendant. Meticulous history regarding the circumstance of assault, whether the perpetrators were known to the victim, whether she protested, whether she was intoxicated or drugged, were taken. Complete general examination including any injury (abrasion, bruise, cuts, tears, fresh bleeding) followed by local examination including perineum, vulva and condition of hymen was performed. Data were tabulated \& percentages are calculated. 


\section{RESULTS}

Out of 53 victims, 51 were female and two male. Maximum numbers of study population were aged between 21-30 years (40\%) while the age range 11-20 years (36\%) was the second highest in the list. $15 \%$ of the cases were of age range 5-10 years. 36\% of the cases were below 18 while $64 \%$ cases were above 18 years of age. 46 victims consented for medical examination while remaining 7 did not consent. In 47 cases alleged perpetrator of the crime was known to the victims. In 25 (47\%) cases sexual acts were consensual as per history and forced in 28 (53\%) cases. Only 3 cases (6\%) gave history of intoxication. On genital examination 18 victims show fresh hymenal tear, 22 show old healed tears and hymen was found intact in 4 cases. The external genitalia and vulva showed fresh tear in 6 cases, congestion in 6 cases, and complete perineal tear in 4 and in 28 cases it appeared to be normal. 30 cases (57\%) give history of being habituated to sexual intercourse while 17 cases (32\%) deny any such habituation. 12 of the victims (23\%) were married, 3 were divorcee, 2 were widow and 34 $(63 \%)$ were unmarried.

\section{DISCUSSION}

Of the total number of victims 51 were females while 2 of the victims were young male child. $36 \%$ of the victims were below 18 years of age. A previous study by RAINN ${ }^{[6]}$ (Rape Abuse Incest National Network) says that in America $80 \%$ of the cases are under age of 30 while $44 \%$ cases are under age 18 . Our present study corroborated with the findings. It shows that most of them victims who faced sexual assault were young females. Traditionally rape laws have been gender specific, providing that only women could be victims of rape and only men could be rapist. However there are issues involving male rape where a male commits forcible anal or oral intercourse on another male. ${ }^{[2]}$ It is obvious from this study that child abuse is not uncommon in our society. A study by D Brown et al says that the incidence of child sexual abuse is all too common. In the United States, reports of child abuse suggest that approximately $25 \%$ to $35 \%$ of women and $10 \%$ to $20 \%$ of men describe being sexually abused as children. ${ }^{[3]}$ The fact that child sexual abuse is perpetrated most frequently by family members, relatives, neighbors or others known to the victims is brought out by many studies. ${ }^{[4]}$ The denial to consent for medico legal examination as noted in 7 out of 53 victims may be due to several causes like trying to avoid the humiliation of medical examination, or when the victim is too afraid of the medical examination procedure itself. Another common cause is that the victim does not want the medical examination as in some cases she is forced by parents to make an allegation against a person whom she loves and the victim herself does not want the case to proceed. According to a study women often try to cope with sexual assault without assistance as she is afraid that the criminal justice system will not believe her or blame her for the assault. ${ }^{[5]}$ In $89 \%$ of the cases the alleged assailant was familiar to the victim while only in $11 \%$ cases it was not. This finding corroborates with the statistics of RAINN which says that about $2 / 3$ rd of the assaults are committed by someone known to the victim. ${ }^{[6]}$ In $53 \%$ cases there was history of forced physical relation while in remaining $47 \%$ cases the sexual act was consensual. When no actual physical violence was used (i.e. coercion or force-only) many abusers will deny that rape has actually occurred and treat the abuse as though it was normal and by mutual consent. This has the effect of further confusing the victim as to the reality of her experience. ${ }^{[7]}$ In an American based study (1971) stated that forcibly committed rape is the most frequent violently committed crime in America. ${ }^{[8]}$ Also on contrary to the common rape myth that the victim is responsible for the assault the truth is that no behaviour warrants a victim to be raped. Rape and sexual assaults are never the victims' fault. ${ }^{[8]}$ Only 3 cases $(6 \%)$ gave history of intoxication. It is noteworthy that an important physical reaction to sexual assault may be an increased indulgence to alcohol, overeating and other addictive behaviour. In $97 \%$ of the alcohol-related sexual assaults, both the victim and the perpetrator had consumed alcohol. The fact that college sexual assaults occur in social situations in which men and women are typically drinking together makes it difficult to examine hypotheses about the unique effects of perpetrators' or victims' intoxication. ${ }^{[9]} 57 \%$ of the cases were habituated to sexual intercourse while $32 \%$ of the cases were not habituated. This consideration was not applicable in $11 \%$ cases including those who did not consent for the medical examination or are too young to be considered. The Hymen was found intact in $7 \%$ of cases and fresh tears noted in $34 \% .42 \%$ cases showed old healed tears. In $17 \%$ of the cases this test was not conducted and this included the male victim and the victims who did not consented. The hymen, contrary to common notion, is often a slack, thick, folded, stretchable tissue which may persist after digital or penile penetration. Findings secondary to sexual abuse are often subtle. Acute tears or bruising are rare because force is seldom a part of the sexual acts committed against a child. ${ }^{[10]}$ On examination of the genitalia, $11 \%$ cases showed fresh wounds while in $8 \%$ cases complete perineal tear was noted. $11 \%$ of the cases showed congestion while in $53 \%$ cases no visible injury could be detected. Injuries in and around private parts were mostly found in minors and children of under 10 years. In adult habituated female victims the genital injuries were absent mostly. Moreover 7 adult victims (13\% of total no of victims) gave history of breach of trust for which they brought the allegation of assault against their partners. Moreover in $9(17 \%)$ cases, on interviewing the victim, it was revealed that the victim is married to the alleged perpetrator out of love affair and complaint has been lodged by the aggrieved 
parents who were unhappy with the marriage. While considering marital status of the victims $63 \%$ of the victims were unmarried, $23 \%$ were married, $6 \%$ were divorced and $4 \%$ were widow. 2 cases $(4 \%)$ of the total number of victims were male. Thus it appears that although the total number of unmarried victims is the highest yet the offence is not merely limited to unmarried population only. Widows and divorcee women who are compelled to live alone may also face this brutal crime as they are sometimes soft target to the perpetrators. Divorced and separated women were also 8 times more likely (25\%) than married women (3\%) to have violence threatened or used against them. ${ }^{[11]}$

\section{TABLES}

Table 1: Different Medico legal Aspects of victims ( $\mathrm{N}=53)$

\begin{tabular}{|c|c|c|}
\hline Medico legal aspects & No. of study population & Percentage (\%) \\
\hline Gave consent for medical examination & 46 & 87 \\
\hline Alleged assailant familiar to victim & 47 & 89 \\
\hline Consensual sexual act & 25 & 47 \\
\hline Forced sexual act & 28 & 53 \\
\hline Victims intoxicated at the time of assault & 03 & 6 \\
\hline No of victims habituated to intercourse & 30 & 57 \\
\hline Condition of hymen & \multirow[b]{2}{*}{$\begin{array}{c}18 \\
22 \\
4 \\
9\end{array}$} & \multirow[b]{2}{*}{$\begin{array}{c}34 \\
42 \\
8 \\
17\end{array}$} \\
\hline $\begin{array}{l}\text { Fresh Tear } \\
\text { Old Tears } \\
\text { Intact Hymen } \\
\text { Not Applicable } \\
\end{array}$ & & \\
\hline Presence of Vulval injury in victims & \multirow[b]{2}{*}{$\begin{array}{c}28 \\
6 \\
6 \\
4 \\
9\end{array}$} & \multirow[b]{2}{*}{$\begin{array}{c}53 \\
11 \\
11 \\
8 \\
17\end{array}$} \\
\hline $\begin{array}{l}\text { Normal } \\
\text { Congestion } \\
\text { Fresh Tear } \\
\text { Complete Perineal Tear } \\
\text { Not Applicable }\end{array}$ & & \\
\hline Presence of Extra Genital injury & 27 & 51 \\
\hline
\end{tabular}

Table 2: Socio Demographic Profile of Study Population ( $\mathrm{N}=53$ )

\begin{tabular}{|c|c|c|}
\hline $\begin{array}{c}\text { Socio Demographic } \\
\text { Characters }\end{array}$ & No. of study population & Percentage (\%) \\
\hline Age & 0 & 0 \\
Below 5 years & 8 & 15 \\
$11-20$ years & 18 & 36 \\
$21-30$ years & 21 & 40 \\
31-40 years & 5 & 9 \\
Above 40 & 0 & 36 \\
years Below 18 & 19 & 64 \\
years & & 23 \\
Marital status ofvictims & 34 & 6 \\
Unmarried & 12 & 4 \\
Married & 3 & \\
Divorcee & 2 & \\
Widow & 2 & \\
Applicable & & \\
\hline
\end{tabular}

\section{CONCLUSION}

Sex related offence continues to be a terror to the society. Although most of the offences were conducted against young and unmarried females, children and married females are also among common victims of this heinous crime. Most of the victims had fallen prey to the lust of their known people but sexual act was committed by force in more than $50 \%$ cases. Devastating physical injuries and injury to private parts were noted in case of child victims. It appears that to prevent this violent crime in society not only stringent laws are to be framed and enacted but also proper education regarding woman rights, health care facilities and continuous efforts to raise consensus against the crime needs to be maintained. 


\section{REFERENCES}

[1] Rape Abuse and Incest National Network [Online] Available from http://www.rainn.org/statistics dated 18/4/2013

[2] Aggrawal Anil Forensic and Medico -legal Aspects of Sexual Crimes and Unusual Sexual Practices, Chapter 10: Rape, CRC Press Taylor \& Francis group, 2009, page 212

[3] Donalee Brown, Sonia Reyes, Brienne Brown \& Meredith Gonzenbach (2013): The Effectiveness of Group Treatment for Female Adult Incest Survivors, Journal of Child Sexual Abuse, 22:2 Available from: http://www.tandfonline.com/doi/pdf/10.1080/10538712.2013.737442 dated 18/4/2013

[4] Aggrawal Anil, Forensic and Medico -legal Aspects of Sexual Crimes and Unusual Sexual Practices, Chapter 2: Pedophilia \& Child Sexual Abuse, CRC Press Taylor \& Francis group, 2009, page 53

[5] Patricia L. Fanflik. Victim response to sexual assault counteractive or simply adaptive [Online] .August 2007Available from: https://www.vaw.umn.edu/documents/victimresponsesexualassault/victimresponsesse xualassaultpdf.pdf Cited18/04/2013

[6] Rape Abuse and Incest National Network [Online] Available from http://www.rainn.org/statistics dated 18/4/2013

[7] Hidden Art Domestic Abuse Information [Online].Available from http://www.hiddenhurt.co.uk/sexual_abuse.html cited on $18 / 4 / 2013$

[8] Baujat Patricia L. Fanflik. Victim response to sexual assault counteractive or simply adaptive[Online] .August 2007 fromhttps://www.vaw.umn.edu/documents/victimresponsesexualassault/victimresponsessexualassaultpdf.pdfCited18/04/2013

[9] Antonia Abbey, PH.D., 143-152 Alcohol-Related Sexual Assault: A Common Problem among college students. http://www.collegedrinkingprevention.gov/media/journal/118-abbey.pdf

[10] Marcia E. Herman-Giddens, Thomas E. Frothingham, Prepubertal Female Genitalia: Examination for Evidence of Sexual Abuse. Available from http://pediatrics.aappublications.org/content/80/2/203.abstract dated 17/4.2013

[11] Kate Painter Wife Rape in The United Angdom http://www.crim.cam.ac.uk/people/academic_research/kate_painter/wiferape.pdf cited 18/4/2013 